\title{
Pancreatic endocrine tissue in benign mediastinal teratoma
}

\author{
PJS DUNN \\ From the Department of Pathology, The Medical School, University of Birmingham, Birmingham B15 2TJ
}

SUMMARY Four cases of benign cystic mediastinal teratoma containing pancreatic tissue have been studied using immunohistochemical and morphometric techniques. The different pancreatic endocrine cell types were stained using antibodies to insulin, glucagon, somatostatin, and pancreatic polypeptide, and the volume density of each cell type was estimated by point counting.

Sections from different regions of the normal adult pancreas were also examined and the results compared. There was an increased total volume density of endocrine cells in the teratomatous pancreas, with a pronounced increase in the proportion of somatostatin containing D cells. The results are similar to those described for pancreatic tissue in neonates, and it is suggested that this is further evidence of altered functional differentiation of the pancreatic tissue found in teratomas.

Teratomas hold a fascination for pathologists because of their widely varying appearances and mysterious pathogenesis. The tissues found in benign cystic teratomas are usually held to be mature and many investigators have studied this maturity using techniques for the demonstration of biochemical markers 1 and cellular antigens ${ }^{2}$ typical of mature tissues. More recently, however, attention has been drawn to altered functional differentiation of exocrine pancreatic tissue within these lesions. ${ }^{3}$

I have systematically quantitated the different cell types of the pancreatic endocrine tissue found in four cases of benign mediastinal teratoma and compared the results with normal adult pancreatic tissue and the reported values found in neonatal pancreatic tissue. There is a consistent pattern to the changes described, with an increased total volume density of endocrine cells and altered relative proportions of the different cell types. This may be further evidence of immaturity of this tissue.

\section{Material and methods}

Four cases of benign mediastinal teratoma were identified from the files of the Department of Pathology, The Medical School, University of Birmingham. In each case the tissue had been removed surgically and fixed in $10 \%$ neutral buffered formalin before routine processing to paraffin wax. Clinical and pathological details are given in Table 1. All four cases contained appreciable amounts of apparently mature pancreatic tissue. The paraffin blocks

Table 1 Clinical and pathological details of four cases of benign mediastinal teratoma

\begin{tabular}{|c|c|c|c|c|c|}
\hline Case no & Age & Sex & Size (cms) & Other tissues present & Presenting complaint \\
\hline 1 & 15 & F & $6 \times 5 \times 5$ & $\begin{array}{l}\text { Epidermoid cysts } \\
\text { Gastrointestinal epithelium } \\
\text { Fibrous tissue, cartilage } \\
\text { Neural tissue }\end{array}$ & Chest pain \\
\hline 2 & 51 & $\mathbf{F}$ & $20 \times 6 \times 5$ & $\begin{array}{l}\text { Epidermoid cysts } \\
\text { Respiratory epithelium } \\
\text { Fibrous tissue } \\
\text { Simple cysts }\end{array}$ & Chest pain \\
\hline 3 & 51 & $\mathbf{F}$ & $10 \times 7 \times 7$ & $\begin{array}{l}\text { Ciliated epithelium } \\
\text { Fibrous tissue with calcification } \\
\text { Lymphoid tissue }\end{array}$ & Routine chest $x$ ray \\
\hline 4 & 17 & $\mathbf{F}$ & $5 \times 5 \times 5$ & $\begin{array}{l}\text { Squamous epithelium } \\
\text { Gastrointestinal epithelium } \\
\text { Muscle }\end{array}$ & Chest pain \\
\hline
\end{tabular}


Table 2 Volume densities of different endocrine cell types in normal adult pancreas

\begin{tabular}{|c|c|c|c|c|c|}
\hline & Insulin cells & Glucagon cells & Somatostatin cells & Pancreatic polypeptide cells & Total endocrine cells \\
\hline $\begin{array}{l}\text { Head (posterior) } \\
\text { Head (anterior) } \\
\text { Body } \\
\text { Tail }\end{array}$ & $\begin{array}{l}1 \cdot 1(0 \cdot 8-1 \cdot 3) \\
1 \cdot 5(1 \cdot 0-2 \cdot 2) \\
2 \cdot 7(2 \cdot 0-3 \cdot 2) \\
3 \cdot 3(2 \cdot 7-3 \cdot 8)\end{array}$ & $\begin{array}{l}0.2(<0.1-0.3) \\
0.3(0.1-0.5) \\
0.7(0.4-0.9) \\
0.9(0.3-1.4)\end{array}$ & $\begin{array}{l}0.2(0.1-0.3) \\
0.2(0.1-0.3) \\
0.2(0.1-0.3) \\
0.3(0.2-0.4)\end{array}$ & $\begin{aligned} & 2 \cdot 2(1 \cdot 5-2 \cdot 5) \\
< & 0 \cdot 1 \\
< & 0.1 \\
< & 0.1\end{aligned}$ & $\begin{array}{l}3 \cdot 7(2 \cdot 4-4 \cdot 4) \\
2 \cdot 0(1 \cdot 2-3 \cdot 0) \\
3 \cdot 6(2 \cdot 5-4 \cdot 4) \\
4 \cdot 5(3 \cdot 2-5 \cdot 6)\end{array}$ \\
\hline
\end{tabular}

Values are mean volume density $(\%)$ with range in parentheses.

were recovered and serial $5 \mu \mathrm{m}$ sections were cut from each of them.

Normal adult pancreatic tissue was obtained from four cases of sudden traumatic death in previously healthy women. Blocks were taken from the anterior head, posterior head, body, and tail, and processed and sectioned in the same manner.

\section{IMMUNOCYTOCHEMISTRY}

All antisera were obtained commercially: guineapig antiserum to porcine insulin, rabbit antiserum to cyclic somatostatin coupled to keyhole limpet haemocyanin, and sheep antiserum to rabbit immunoglobulins were supplied by RIA UK Ltd (Washington, Tyne and Wear). Rabbit antiserum to glucagon and soluble horseradish peroxidase-rabbit antiperoxidase complex were supplied by Mercia Brocades (West Byfleet, Surrey). Immunostaining and appropriate controls were performed as previously described ${ }^{4}$ after treatment of dewaxed sections with trypsin..$^{5}$ In addition, sections were stained using rabbit antipancreatic polypeptide (Milab, Malmo, Sweden) as first layer, without prior trypsinisation, at a titre of $1 / 640$.

A fifth section from each block was stained with haematoxylin and eosin for routine histological evaluation and identification of those blocks containing pancreatic tissue.

\section{MORPHOMETRY}

The volume density of the different endocrine cell types was estimated using the point counting method of Chalkey ${ }^{6}$ as described by Rahier et al. ${ }^{7}$ The sections were examined at a linear magnification of $\times 160$ using a 42 point lattice (Graticules Ltd, Tonbridge, Kent). In the case of the control pancreatic tissue, each section was examined systematically and all fields were counted. For the teratoma sections, the areas occupied by pancreatic tissue were delineated under low power on the haematoxylin and eosin stained sections and the identical regions outlined with felt tipped pen on the coverslips of the immunostained sections by superimposition over a bright light source. Only the areas thus delineated were point counted.

The volume density of each endocrine cell type was calculated as the ratio of points falling on that cell type to the number falling on all epithelial cells and excluding points falling on connective tissue elements. The total volume density of endocrine tissue was obtained by summation of the values for each endocrine cell type. The results for the four teratomas are given individually. The values for the adult pancreas are given as the means for each region with the range.

\section{Results}

The adult female pancreatic tissue showed n@ abnormality by light microscopy. The mean volume densities of the different endocrine cells are shown in Table 2. The endocrine cells were generally confined to islets, where insulin positive B cells were arranged centrally with a peripheral rim of glucagon positive $A$ and somatostatin positive $D$ cells. Pancreatic polypeptide cells were present in any number only in the posterior part of the head, where there were a few small aggregates of these cells not related to recognisable islets. The islet sections were all round or oval with clearly defined margins. The results are not appreciably different from those previously reported by other investigators using similar methods. ${ }^{78}$

The pancreatic tissue from the teratomas showed a wide variation in endocrine cell content (Table 3 ). The total volume density of endocrine cells was significantly increased compared with the controls. In one case (no 2), endocrine cell volume density

Table 3 Volume densities of different endocrine cell types in four cases of mediastinal teratoma

\begin{tabular}{llllll}
\hline Case no & Insulin cells & Glucagon cells & Somatostatin cells & Pancreatic polypeptide cells & Total endocrine cells \\
\hline 1 & 6.7 & 1.0 & 5.8 & 0.9 & 14.4 \\
2 & 28.9 & 4.2 & 12.9 & 0.7 & 46.7 \\
3 & $3 \cdot 2$ & 0.5 & 2.0 & 0.1 & $5 \cdot 7$ \\
4 & $9 \cdot 1$ & 0.8 & 5.5 & 0.2 & 15.6 \\
Mean (SEM) & $11.98(4.9)$ & $1.6(0.74)$ & $6.55(1.97)$ & $0.45(0.18)$ & $20.6(7.77)$ \\
\hline
\end{tabular}

Values are volume density $(\%)$. 


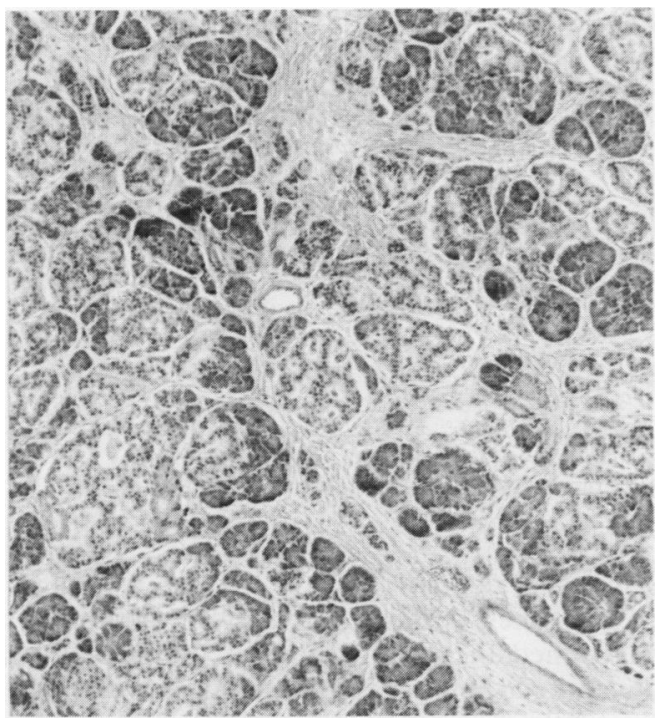

Fig. 1 Exocrine and endocrine pancreatic tissue from teratoma. The islets are numerous and large. Most contain multiple lumina lined by endocrine cells. Haematoxylin and eosin. $\times 16$.

approached $50 \%$, and this increase was readily apparent on examination of the haematoxylin and eosin stained sections. In the other cases the increase was only shown by morphometric examination.

The islets showed a pronounced variation in shape and regularity of outline. The larger islets were lobulated and arranged around multiple duct like lumina (Fig. 1). Some were traversed by true ducts lined by non-endocrine epithelial cells. In case 2 the increased volume density of endocrine tissue was so

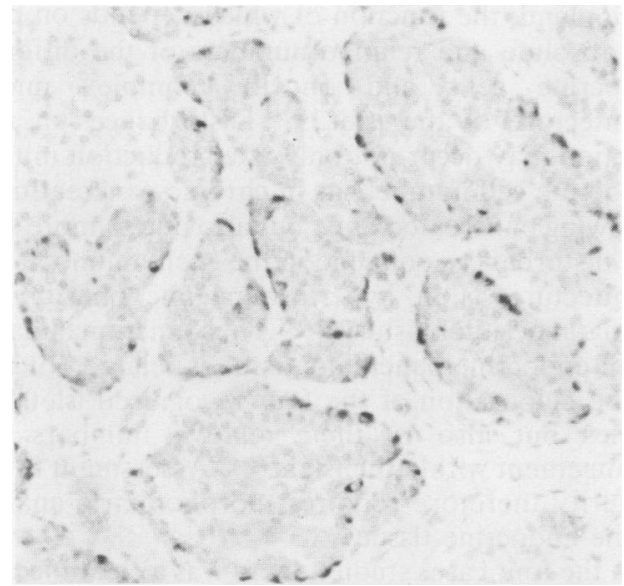

Fig. 2 Pancreatic tissue from teratoma. Section stained for glucagon showing peripheral rim of positive cells around enlarged islets. PAP technique for glucagon. $\times 40$.

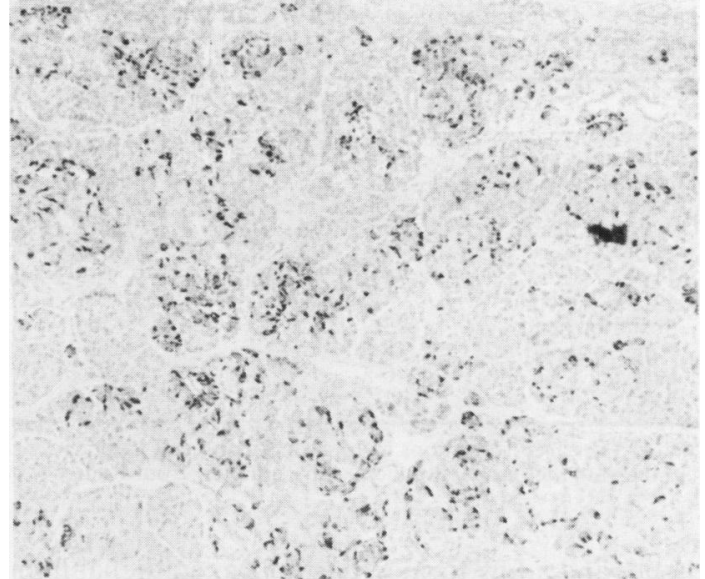

Fig. 3 Pancreatic tissue from teratoma. There is a pronounced increase in endocrine cell density and in the proportion of somatostatin containing cells compared with normal tissue. PAP technique for somatostatin. $\times 16$.

pronounced in some areas that the normal arrangement of exocrine and endocrine cells appeared reversed with islands of exocrine cells surrounded by endocrine tissue.

The majority of endocrine cells in each case were insulin containing B cells. These were mostly located within the islets, where they formed a central core as in the normal pancreas. In all cases vacuolation of $B$ cells was a prominent feature. A few B cells were present singly, scattered among exocrine pancreatic

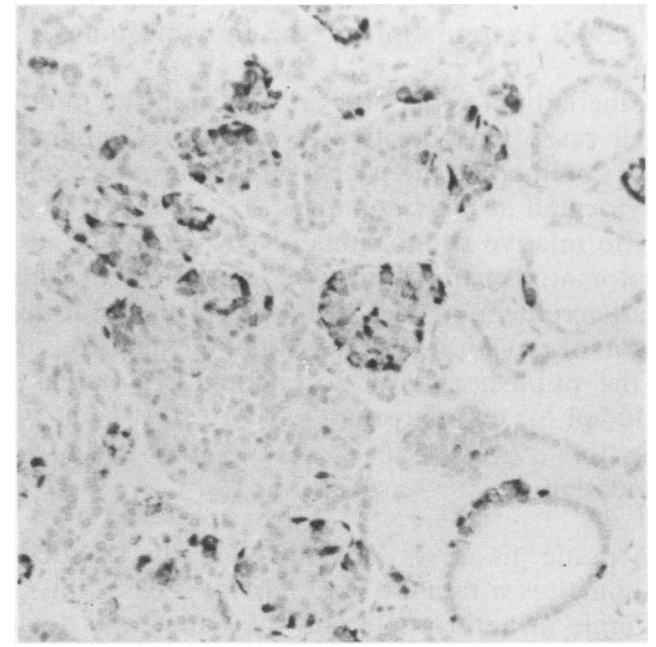

Fig. 4 Pancreatic tissue from teratoma. Somatostatin containing cells are present at the periphery of islets and within ductal epithelium. PAP technique for somatostatin. $\times 40$. 
Table 4 Proportion of each cell type in the four teratomas studied and in the different regions of the adult and neonatal pancreas

\begin{tabular}{|c|c|c|c|c|}
\hline & Insulin cells & Glucagon cells & Somatostatin cells & Pancreatic polypeptide cells \\
\hline \multirow{2}{*}{$\begin{array}{l}\text { Teratoma ( } 4 \text { cases) } \\
\text { Adult pancreas ( } 4 \text { cases) }\end{array}$} & $55 \cdot 8(46 \cdot 5-58 \cdot 3)$ & $7 \cdot 4(5 \cdot 1-9 \cdot 0)$ & $34 \cdot 5(27 \cdot 6-40 \cdot 3)$ & $2 \cdot 3(0 \cdot 1-6 \cdot 3)$ \\
\hline & & & & \\
\hline Posterior head & $29 \cdot 6(25 \cdot 6-32)$ & $5 \cdot 2(2 \cdot 6-7 \cdot 5)$ & $5 \cdot 2(4-6 \cdot 8)$ & $60 \quad(55-66 \cdot 7)$ \\
\hline Anterior head & $75.9(70 \cdot 6-83 \cdot 4)$ & $14 \cdot 2(8 \cdot 3-17 \cdot 6)$ & $9.9(8 \cdot 3-11 \cdot 8)$ & - \\
\hline Body & $75 \cdot 5(72 \cdot 7-80)$ & $19 \cdot 1(16-20 \cdot 5)$ & $5 \cdot 4(4-6 \cdot 8)$ & - \\
\hline Tail & $74.4(67 \cdot 9-84 \cdot 4)$ & $19(9 \cdot 4-25)$ & $6.6(6 \cdot 2-7 \cdot 1)$ & - \\
\hline \multicolumn{5}{|l|}{ Neonatal pancreas* } \\
\hline Posterior head & $23 \cdot 9$ & $6 \cdot 5$ & $17 \cdot 4$ & $52 \cdot 2$ \\
\hline Anterior head & $45 \cdot 5$ & $21 \cdot 2$ & $32 \cdot 7$ & 0.6 \\
\hline Body & 40.5 & $29 \cdot 1$ & $30 \cdot 4$ & - \\
\hline Tail & $41 \cdot 2$ & $22 \cdot 3$ & $35 \cdot 1$ & $1 \cdot 4$ \\
\hline
\end{tabular}

Values $(\%)$ are proportions of total endocrine cell volume density contributed by each cell type with range in parentheses.

*Values for the neonatal pancreas are adapted from Rahier et al: The endocrine pancreas of human neonates and infants.'

tissue, and a few formed part of the epithelial lining of larger ducts.

The glucagon containing A cells were much less numerous than B cells. They also occurred mostly within the islets, where they formed a discontinuous peripheral rim, an identical pattern to that seen in the normal islet (Fig. 2). No separate clusters were seen and no A cells were present within ductal epithelium.

The somatostatin containing D cells were extremely prominent in all cases (Fig. 3 ). They were present at the periphery of islets as expected but also in multiple irregular clusters, often in association with small ducts and within the epithelial lining of larger ducts (Fig. 4). The volume density of D cells showed a 7-40-fold increase compared with the most densely populated region of the normal adult pancreas - a striking increase, and readily apparent on casual examination of the immunostained sections.

Pancreatic polypeptide cells were in the minority in all cases. The positive cells occurred singly and were confined to the islets, where they were generally located at the periphery.

The relative proportions of each cell type in the teratomatous pancreatic tissue are shown in Table 4. The percentage of each cell type calculated for each region of the adult pancreas and the values reported in the published work for neonatal pancreas are included for comparison.

\section{Discussion}

Pancreatic tissue is not infrequently situated in ectopic sites within the body. ${ }^{9}$ In most cases this is an example of heterotopia and the pancreatic tissue is present only in microscopic quantities. Benign cystic teratomas, however, may contain pancreatic tissue in larger amounts, and this is a particularly common finding in tumours from the mediastinum ${ }^{10}$ and sac- rococcygeal region. ${ }^{3}$

The tissues found within benign teratomas are well formed and usually considered to be mature by conventional microscopy, although arranged in an apparently haphazard fashion. Recent published work, however, has shown evidence of functional immaturity of exocrine pancreatic tissue in teratomas, as judged by the production of immunoreactive amylase. ${ }^{3}$ It was suggested that this immaturity might reflect a disturbance in the system that controls functional differentiation. It is currently believed that the exocrine and endocrine cells of the pancreas differentiate from common precursor cells within ductal epithelium, ${ }^{11}$ a view which is supported by the apparently invariable presence of both tissue types in extra pancreatic sites. Consequently, any disturbance in the control of differentiation of exocrine pancreatic tissue might also be reflected in the endocrine cells.

The normal pancreatic islet is a complex endocrine gland, the function of which depends on both the absolute and relative numbers of the different endocrine cells and on the complex microarchitecture of the islet. ${ }^{1213}$ Disturbances in islet funçtion may occur not only after reduction in total endocrine cell numbers as in chronic pancreatitis or following pancreatectomy, but also due to more subthe disturbances of endocrine cell numbers or architecture as in hyperinsulinaemic obesity and neonatal nesidioblastosis. ${ }^{14}{ }^{15}$ Thus functional maturity of endocrine pancreatic tissue is related not only to the elaboration of the four recognised islet hormones but also to their relative numbers and arrangement within the islets. ${ }^{16}{ }^{17}$ Assessment of this maturity therefore requires morphometric analysis of the endocrine tissue.

In the four cases studied there was a clear increase in the total volume density of endocrine cells as compared with any region of the normal adult pancreas. There was also a striking alteration in the 
proportions of the various cell types present. This was most striking for the somatostatin containing D cells. These accounted for between $27.6 \%$ and $40.3 \%$ of the total volume density of endocrine cells in the teratomas as compared with a maximum of $12 \%$ in any region of the normal adult pancreas.

The increased volume density of endocrine cells may be due either to a disproportionate increase in formation of endocrine cells or a decreased formation of exocrine tissue. The presence of endocrine cell clusters of single cell type and increased numbers of endocrine cells within ductal epithelium would favour the former. The alterations in architecture and proportions of cells might be interpreted as simply a feature of the haphazard arrangement of tissues found in teratomas. The formation of complex islets and recognisable pancreatic tissue, however, with neither component occurring in isolation, would suggest a less random phenomenon. The same trends present in all four cases studied would also support the hypothesis that these are not random changes. Published studies on the endocrine pancreatic tissue of neonates ${ }^{78}$ show similar alterations compared with normal adult pancreatic tissue. In this age group the mean volume density of endocrine tissue is $15 \%$ and $D$ cells account for roughly $30 \%$ of the total, with a reduced proportion of B cells. It is therefore suggested that the changes noted in the pancreatic endocrine tissue of teratomas are due to immaturity of the pancreatic tissue and that this is further evidence of altered functional differentiation within this tissue.

Review of the published work reveals only one case of proven pathological hormone production by teratomatous pancreatic tissue. ${ }^{19}$ This was a case of mediastinal teratoma similar to those reported here. In this case there was asymptomatic hypoglycaemia and a raised serum immunoreactive insulin concentration, which was cured by removal of the teratoma. Histological examination showed pancreatic tissue with large islets. None of the four cases described in this report was specifically investigated for endocrine abnormality before surgery. All had random blood glucose values within the normal range. Case 2 , perhaps significantly the largest tumour, did show unexplained hyperglycaemia and glycosuria for two days postoperatively, which subsequently returned to normal. The rarity of clinically evident abnormal function by teratomatous pancreatic tissue may not be surprising in view of the presence of a comparatively much larger volume of functioning endocrine tissue within the normal pancreas.

The evidence presented in this paper shows that the endocrine pancreatic tissue seen in mediastinal teratomas differs from normal both in total volume density and, perhaps more importantly, in relative proportions of the different endocrine cells. There is a pronounced resemblance to immature pancreatic tissue as seen in neonates, and it is suggested that the changes are further evidence of abnormal functional differentiation in this tissue. Whether this abnormal differentiation is an integral feature of teratomas or of all ectopic pancreatic tissue is unclear and might shed further light on the control mechanisms which operate in the normal pancreas.

I would like to thank Mr J Gregory for expert technical assistance and Miss A Wright for typing the manuscript. I should also like to thank Dr TP Rollason for drawing these four cases to my attention.

\section{References}

' Hasleton PS, Kelehan P, Whittaker JS, et al. Benign and malignant struma ovarii. Arch Pathol Lab Med 1978;102:180.

${ }^{2}$ Pertschuk LP. Epithelial and muscle antigens in benign cystic teratomas of the ovary. Cancer Res 1975:35:750.

${ }^{3}$ Hodes JE, Meredith TH, Mirkin LD, Hodes ME. Immunohistochemical demonstration of altered functional differentiation of pancreatic tissue in sacrococcygeal teratomas. Human Pathol 1983; 14:724-6.

4 Dunn PJS, Sheppard MC, Heath DA, Slaney G. Recurrent insulinoma syndrome with metastatic glucagonoma. J Clin Pathol 1983;36: 1076-80.

s Curran RC, Gregory J. The unmasking of antigens in paraffin sections of tissue by trypsin. Experientia $1977 ; 33: 1400-1$.

6 Chalkey HW. Method for the quantitative morphologic analysis of tissues. J Natl Cancer Inst 1943;4:47-53.

7 Rahier J, Wallon J, Henquin JC. Cell populations in the endocrine pancreas of human neonates and infants. Diabetologia $1981 ; 20: 540-6$

${ }^{8}$ Rahier J, Goebbels RM, Henquin JC. Cellular composition of the human diabetic pancreas. Diabetologia 1983:24:366-71.

- Willis RA. The borderland of embryology and pathology. London: Butterworths Medical Publications, 1958:317-20.

${ }^{10}$ Schumberger HG. Teratoma of the anterior mediastinum in the group of military age. Arch Pathol 1946;41:398.

" Like AA, Orci L. Embryogenesis of the human pancreatic islets: a light and electron microscopic study. Diabetes 1972;21 (suppl 2):511.

12 Baetens D, Stefan Y, Ravavasola M, Malaisse-Lagae F, Coleman DL, Orci L. Alterations of islet cell populations in spontaneously diabetic mice. Diabetes $1978 ; 27: 1-7$.

${ }^{13}$ Orci L, Unger RH. Hypothesis: Functional subdivision of islets of Langerhans and possible role of D-cells. Lancet 1975;ii: $1243-4$.

${ }^{14}$ Ogilvie RT. The islands of Langerhans in 19 cases of obesity. $J$ Pathol Bacteriol 1933;37:473-81.

15 Bishop AE, Polak JM, Chesa PG, Timson CM, Bryant MG, Bloom SR. Decrease of pancreatic somatostatin in neonatal nesidioblastosis. Diabetes 1981; 30: 122-6.

${ }^{16}$ Unger RH, Orci L. Possible roles of the pancreatic D-cell in the normal and diabetic states. Diabetes 1977;26:241-4.

17 Unger RH, Orci L. Glucagon \& the A-cell. N Eng J Med 1981;304: 1575-80.

${ }^{18}$ Rahier J, Wallon J, Henquin JC. Abundance of SRIF cells in the human neonatal pancreas. Diabetologia 1980;18:251-4.

19 Honicky RE, de Papp EW, Rochester NY. Mediastinal teratoma with endocrine function. Am J Dis Child 1973;126:650-3. 